\title{
PERBEDAAN PENINGKATAN KEMAMPUAN PEMECAHAN MASALAH BIOLOGI SISWA DENGAN MENGGUNAKAN MODEL KOOPERATIF TEAM ASSISTED INDIVIDUALIZATION DAN PROBLEM BASED LEARNING
}

\section{DIFFERENCES INCREASING STUDY OF SOLID STUDY BIOLOGIC PROBLEMS USING COOPERATIVE LEARNING MODEL TEAM ASSISTED INDIVIDUALIZATION AND PROBLEM-BASED LEARNING MODEL}

\author{
Rahmayanti Marasabessy ${ }^{1}$, Djukri $^{2}$ \\ Pendidikan Biologi, FMIPA \\ 1,2 Universitas Negeri Yogyakarta \\ Rahmayantimarasabessy257@gmail.com ${ }^{1}$
}

\begin{abstract}
This research is committed with the aim to determine 1) the increase in the biological problemsolving ability of students after the implementation of TAI type of cooperative models. 2) increase the biological problem-solving ability of students after the implementation of the model PBL models. 3) the improvement of the biological problem-solving ability of students between classes that use the cooperative model TAI with the class using PBL models. The method used is an experiment with the form of quasi-experimental design types of nonequivalent control group design. The instrument used is a matter in the form of essays and the data were analyzed using $N$ Gain and One-Sample t-Test, whereas to know the difference increase in both models using the Independent Sample T-Test.
\end{abstract}

Keywords: Biological Problem Solving Ability, TAI and PBL

\begin{abstract}
Abstrak
Penelitian ini dilakukan dengan tujuan untuk mengetahui 1) peningkatan kemampuan pemecahan masalah biologi siswa setelah diterapkannya model kooperatif tipe TAI dan PBL serta Perbedaan dari kedua mamodel. Metode penelitian yang digunakan adalah eksperimen dengan bentuk quasi eksperimental design tipe nonequivalent control group design. Instrument yang digunakan adalah soal dalam bentuk essay dan data dianalisis menggunakan N-Gain dan One-Sample t Test, sedangkan untuk mengetahui perbedaan peningkatan kedua model menggunakan Independent sample T Test. Hasil analisis menunjukkan bahwa 1) terdapat peningkatan kemampuan pemecahan masalah biologi siswa setelah diterapkannya model kooperatif tipe TAI dan $P B L$ serta tidak terdapat perbedaan peningkatan kemampuan pemecahan masalah biologi antara siswa yang menggunakan model kooperatif TAI dengan kelas yang menggunakan model $P B L$.
\end{abstract}

Kata Kunci: Kemampuan Pemecahan Masalah Biologi, Team Assisted Individualization,s dan Problem-Based Learning. 


\section{PENDAHULUAN}

Penyelenggaraan Pendidikan di Indonesia merupakan suatu sistem pendidikan nasional yang diatur dalam Undang-Undang RI No 20 tahun 2003 pasal 3 tentang tujuan pendidikan nasional. Dalam undang-undang tersebut tertulis pendidikan nasional berfungsi mengembangkan kemampuan dan membentuk watak serta peradaban bangsa yang bermartabat dalam rangka mencerdaskan kehidupan bangsa, bertujuan untuk berkembangnya potensi peserta didik agar menjadi manusia yang beriman dan bertakwa kepada Tuhan Yang Maha Esa, berakhlak mulia, sehat, berilmu, cakap, kreatif, mandiri, dan menjadi warga negara yang demokratis serta bertanggung jawab. Dalam upaya mencapai tujuan tersebut, seorang pendidik yang berkualitas dibutuhkan sehingga pola pembelajaran yang diajarkan dalam proses belajar mengajar mencapai tujuan yang diinginkan.

Rendahnya hasil belajar peserta didik dalam pembelajaran biologi sangat ditentukan oleh guru, karena guru merupakan komponen pembelajaran yang sangat penting dalam kegiatan pembelajaran di kelas [4]. Rendahnya hasil belajar peserta didik ini disebabkan belum efektifnya penggunaan strategi, model, metode dan pendekatan pembelajaran, serta lemahnya penguasaan guru terhadap mata pelajaran. Selain itu, proses pembelajaran masih didominasi oleh guru dan belum memberikan kesempatan bagi peserta didik untuk berkembang secara mandiri, sama halnya dengan yang terjadi di Madrasah Aliya Negeri 1 Kota Ternate.

Dalam lingkup Sekolah Menengah Atas (SMA), pembelajaran biologi terdiri atas sub-sub pokok bahasan. Diantaranya ekosistem, sel, jaringan, pertumbuhan dan perkembangan dan sebagainya. Dari sekian sub-sub pokok bahasan tersebut, salah satu sub pokok bahasan yang menuntut kemampuan pemecahan masalah biologi siswa serta membutuhkan tingkatan berpikir yang lebih tinggi dalam pemecahan masalah adalah sub pokok bahasan ekosistemHasil studi pada MAN 1 Kota Ternate tahun ajaran 2017-2018. Menunjukkan bahwa kemampuan awal siswa sekolah tersebut dalam menyelesaikan masalah yang berkaitan dengan materi ekosistem variabel, berikut ini akan ditunjukkan presentasi hasil studi pendahuluan berdasarkan setiap aspek yang digunakan pada materi sistem ekosistem.

Hasil Penilaian Studi Pendahuluan

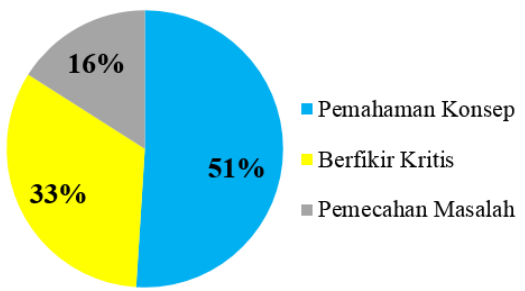

Gambar 1. Grafik Presentasi hasil penilaian studi pendahuluan per-aspek.

Dari beberapa soal yang diberikan ternyata kebanyakan siswa dari sekolah tersebut sangat bermasalah pada menyusun model biologi dan menerapkan strategi untuk menyelesaikan masalah. Menerapkan strategi pemecahan masalah merupakan bagian dari kemampuan pemecahan masalah biologi atau dengan kata lain kemampuan pemecahan masalah biologi siswa kelas $\mathrm{X}$ MAN 1 Kota Ternate masih tergolong rendah. Sehingga pada penelitian ini peneliti memilih untuk melakukan penelitian pada aspek kemampuan pemecahan masalah biologis.

Untuk mengatasi berbagai masalah di atas, diperlukan suatu pembelajaran yang inovatif, salah satu dari pembelajaran inovatif adalah pembelajaran kooperatif. Dalam pembelajaran kooperatif terdapat banyak model pembelajaran diantaranya Team Assisted Individualization, Cooperative Learning tipe Team Assisted Individualization adalah model 
pembelajaran yang mengombinasikan keunggulan pembelajaran kooperatif dan pembelajaran individual [1].

$$
\text { Hasil penelitian Ref. [2] }
$$
menunjukkan penggunaan model pembelajaran kooperatif tipe Team Assisted Individualization dapat meningkatkan hasil belajar matematika tentang operasi hitung pecahan.

Selain model pembelajaran cooperative tipe Team Assisted Individualization ada juga model pembelajaran Problem Based Learning. Problem Based Learning adalah salah satu langkah dalam pembelajaran berbasis masalah yakni pengorganisasian siswa dalam kelompok belajar. Guru memfasilitasi siswa dalam membuat rangkuman, mengarahkan, dan memberikan penugasan pada materi pembelajaran yang telah dipelajari dan guru memfasilitasi siswa agar siswa dapat menggali pengetahuan, mengeksplor pengetahuan, serta menerapkan konsep dari apa yang telah mereka pelajari.

Hasil penelitian Ref [4], bahwa terdapat perbedaan yang sangat signifikan hasil belajar siswa menggunakan model TA. Selain itu Ref. [5] model PBL dapat meningkatkan kemampuan berpikir kritis siswa yang dilihat dari perlakuan beberapa siklus dalam penelitiannya. Pemecahan masalah dalam model PBL juga dapat mengembangkan kemampuan untuk berpikir kritis dan mengembangkan konsep belajar [6]. Richard I. Arends mengungkapkan lima langkah pembelajaran PBL yaitu mendefinisikan masalah, mendiagnosis masalah, merumuskan alternatif strategi, menentukan dan menerapkan strategi pilihan dan melakukan evaluasi [6]. John Dewey seorang ahli pendidikan berkebangsaan Amerika merumuskan enam langkah pembelajaran PBL yaitu: merumuskan masalah, menganalisi masalah, merumuskan hipotesis, mengumpulkan data, menguji hipotesis dan merumuskan rekomendasi [8].
Hasil penelitian Muhammad Fachri Palolang dalam jurnalnya berjudul "Penerapan Model Problem Based Learning (PBL) Untuk Meningkatkan Hasil Belajar Siswa Pada Materi Panjang Garis Singgung Persekutuan Dua Lingkaran di Kelas VIII SMP Negeri 19 Palu", menunjukkan bahwa Penerapan model pembelajaran Problem Based Learning dapat meningkatkan hasil belajar siswa [9]. "A problem is a situation in wich a person is motivated in reach a goal but attaiment of the goal is blocked by some obstacle or obstacles. The person's task is to find a solution to the problem, that is to discover way to overcome the obstacle" [10].

Aspek kemampuan pemecahan masalah matematis sangat cocok dengan beberapa model diantaranya seperti model pembelajaran cooperative tipe Team Assisted Individualization dan model pembelajaran Problem Based learning. Peneliti akan meneliti dua model yang akan dibandingkan sehingga peneliti mengambil model Cooperative tipe Team Assisted Individualization dan Problem Based Learning. Karena peneliti berasumsi kedua model tersebut sangat cocok untuk meningkatkan kemampuan pemecahan masalah biologis siswa, tujuan dari kooperatif adalah pencapaian hasil belajar, penerimaan keberagaman dan keterampilan sosial [11]. Bahan pelajaran merangsang minat siswa sehingga tertarik untuk memecahkan masalah [12]

\section{METODE PENELITIAN}

Penelitian ini merupakan penelitian eksperimen. Dengan desain quasi experimental design tipe nonequivalent control group design. Populasi penelitian ini adalah siswa kelas X MAN 1 Kota Ternate tahun pelajaran 2017/2018 yang berjumlah 71 yang terdiri dari 3 kelas. Sampel penelitian adalah siswa kelas MIA 2 dengan jumlah 24 dan siswa kelas MIA 3 dengan 
Perbedaan Peningkatan Kemampuan Pemecahan Masalah Biologi Siswa dengan Menggunakan Model Kooperatif Team Assisted Individualization dan Problem Based Learning

jumlah 24 siswa. Teknik pengambilan sampel dengan cara purpose sampling. Instrumen yang digunakan berupa tes hasil belajar dengan bentuk tes esai. Teknik pengumpulan data dengan cara observasi, tes uraian, dan dokumentasi. Data dianalisis dengan cara deskripsi [13].

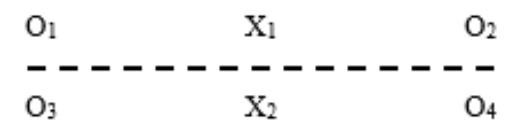

Gambar 2. Nonequivalent Control Group Design

\section{HASIL DAN PEMBAHASAN}

Data hasil tes kemampuan pemecahan masalah bilogi siswa kelas X MAN 1 Kota Ternate tahun ajaran 2017/2018 disajikan pada tabel berikut ini.

Tabel 3. Hasil Tes Kemampuan Pemecahan Masalah

\begin{tabular}{|c|c|c|c|c|}
\hline \multirow{2}{*}{ Deskripsi } & \multicolumn{2}{|c|}{ TAI } & \multicolumn{2}{c|}{ PBL } \\
\cline { 2 - 5 } & Pretest & Posttest & Pretest & Posttest \\
\hline Nilai Minimum & 9 & 44 & 9 & 51 \\
\hline Nilai maksimum & 42 & 93 & 47 & 100 \\
\hline Rata-rata & 26,5 & 67,83 & 22,71 & 73,71 \\
\hline Simpangan Baku & 13,16 & 11,68 & 9,33 & 12,73 \\
\hline
\end{tabular}

Berdasarkan data di atas nilai Pretest tertinggi pada kelas eksperimen dengan model kooperatif tipe TAI bernilai 42 dan nilai Pretest tertinggi pada kelas eksperimen dengan model PBL bernilai 47. Sehingga, secara keseluruhan nilai Pretest tertinggi dari kedua kelas eksperimen tersebut adalah 47. Sedangkan, nilai Posttest tertinggi pada kelas eksperimen dengan menggunakan model kooperatif TAI bernilai 93 dan nilai Posttest tertinggi pada kelas eksperimen dengan model PBL bernilai 100. Sehingga, secara keseluruhan nilai Posttest tertinggi 100 sedangkan nilai terendahnya 44.

Data hasil peningkatan kemampuan pemecahan masalah biologi siswa pada kelas eksperimen dengan menggunakan model kooperatif tipe Team Assisted Individualization (TAI) disajikan pada tabel berikut ini.

Tabel 4. Hasil Peningkatan Kemampuan Pemecahan Masalah TAI

\begin{tabular}{|l|c|c|c|c|}
\hline \multicolumn{1}{|c|}{ Indikator } & Pretest & Posttest & N-Gain (g) & Interpretasi \\
\hline Mengidentifikasi Masalah & 29,17 & 93,52 & 0,91 & Tinggi \\
\hline Menyusun Model & 43,52 & 66,67 & 0,41 & Sedang \\
\hline Memilih strategi & 15,28 & 87,5 & 0,85 & Tinggi \\
\hline Menerapkan strategi & 29,63 & 54,17 & 0,35 & Sedang \\
\hline Memeriksa kebenaran jawaban & 14,81 & 37,04 & 0,26 & Rendah \\
\hline
\end{tabular}

Data hasil peningkatan kemampuan pemecahan masalah biologi siswa pada kelas eksperimen dengan menggunakan model Problem Based Learning (PBL) disajikan pada tabel berikut ini.

Tabel 5. Hasil Peningkatan Kemampuan Pemecahan Masalah PBL

\begin{tabular}{|l|c|c|c|c|}
\hline \multicolumn{1}{|c|}{ Indikator } & Pretest & Posttest & N-Gain (g) & Interpretasi \\
\hline Mengidentifikasi Masalah & 38,89 & 95,83 & 0,93 & Tinggi \\
\hline Menyusun Model & 38,43 & 80,11 & 0,68 & Sedang \\
\hline Memilih strategi & 16,67 & 87,96 & 0,86 & Tinggi \\
\hline Menerapkan strategi & 19,44 & 56,02 & 0,45 & Sedang \\
\hline Memeriksa kebenerann jawabann & 1,85 & 42,13 & 0,41 & Sedang \\
\hline
\end{tabular}

Dari hasil peningkatan kemampuan pemecahan masalah biologis pada kelas Team Assisted Individualization (TAI) dan kelas Problem Based Learning (PBL), berikut ini akan ditunjukkan hasil interpretasi peningkatan kemampuan pemecahan masalah biologi pada kelas eksperimen dengan menggunakan model kooperatif tipe TAI dan PBL secara keseluruhan.

Tabel 6. Analsis Peningkatan Kemampuan Pemecahan Masalah

\begin{tabular}{|c|c|c|c|c|}
\hline Kelas Eksperimen & Pretest & Posttest & N-Gain $(\mathrm{g})$ & Interpretasi \\
\hline TAI & 26,5 & 67,83 & 0,56 & Sedang \\
\hline PBL & 22,71 & 73,71 & 0,66 & Sedang \\
\hline
\end{tabular}

Berdasarkan tabel 6 di atas, N-Gain (g) pada kelas eksperimen 1 dengan model kooperatif tipe TAI bernilai 0,56. Nilai tersebut berada pada kategori sedang, sedangkan N-gain (g) pada kelas eksperimen II dengan model PBL bernilai 0.66 , nilai tersebut berada pada kategori sedang. Sehingga, dapat disimpulkan kedua kelas eksperimen tersebut memiliki N-Gain (g) sedang yang berarti kedua kelas eksperimen memiliki peningkatan kemampuan pemecahan masalah biologi yang sedang.

Hasil uji One Sample t-test untuk model kooperatif tipe Team Assisted 
Individualization disajikan pada tabel berikut.

Tabel 8. Uji Peningkatan Kemampuan Pemecahan Masalah Biologi pada Kelas Team Assisted Individualization dengan Program SPSS 24.

\begin{tabular}{|c|c|c|c|c|c|}
\hline \multirow{2}{*}{$\mathbf{t}$} & \multirow{2}{*}{ Df } & \multirow{2}{*}{ Sig. (2-tailed) } & \multirow{2}{*}{$\begin{array}{c}\text { Mean } \\
\text { Difference }\end{array}$} & \multicolumn{2}{|c|}{$\begin{array}{c}\text { 95\% Confidence } \\
\text { Interval of the } \\
\text { Difference }\end{array}$} \\
\cline { 5 - 6 } & & & & Lower & Upper \\
\hline 28.462 & 23 & 0.000 & 67.8333 & 62.9032 & $\begin{array}{c}72.763 \\
5\end{array}$ \\
\hline
\end{tabular}

Berdasarkan data yang disajikan pada tabel di atas, dapat diketahui pada kelas Team Assisted Individualization dengan $D f=$ 23 diperoleh taraf $\frac{\operatorname{sig}(2-\text { tailed })}{2}=0.000$. nilai signifikan pada kelas Team Assisted Individualization memiliki nilai yang kurang dari $\alpha=0,05(0.000<0,05)$ dimana hal ini menunjukkan tolak $H_{0}$. Oleh karena $H_{0}$ ditolak maka terdapat peningkatan kemampuan pemecahan masalah biologi siswa yang menggunakan model kooperatif tipe Team Assisted Individualization.

Tabel 9. Hasil Uji Peningkatan Kemampuan Pemecahan Masalah Biologi pada Kelas Problem Based Learning dengan Program SPSS

\begin{tabular}{|c|c|c|c|c|c|}
\hline \multirow{2}{*}{$\mathbf{t}$} & \multirow{2}{*}{ Df } & \multirow{2}{*}{ Sig. (2-tailed) } & \multirow{2}{*}{$\begin{array}{c}\text { Mean } \\
\text { Difference }\end{array}$} & \multicolumn{2}{|c|}{$\begin{array}{c}\text { 95\% Confidence } \\
\text { Interval of the } \\
\text { Difference }\end{array}$} \\
\cline { 5 - 6 } & & & & Lower & Upper \\
\hline 28.374 & 23 & 0.000 & 73.70833 & 68.334 & 79.082 \\
& & & & 1 \\
\hline
\end{tabular}

Berdasarkan data yang disajikan pada tabel di atas, dapat diketahui pada kelas Problem Based Learning dengan Df $=23$ diperoleh taraf $\frac{\text { sig }(2-\text { tailed })}{2}=0.000$. nilai signifikan pada kelas Problem Based Learning memiliki nilai yang kurang dari $\alpha$ $=0,05(0.000<0,05)$ dimana hal ini menunjukkan tolak $H_{0}$. Oleh karena $H_{0}$ ditolak maka terdapat peningkatan kemampuan pemecahan masalah biologis siswa yang menggunakan model Problem Based Learning.
Dari kedua penjelasan di atas, dapat disimpulkan bahwa terdapat peningkatan kemampuan pemecahan masalah biologi siswa antara kelas yang menggunakan model kooperatif tipe Team Assisted Individualization dengan kelas yang menggunakan model Problem Based Learning.

Tabel 10. Hasil Independent Sample-T Test Setelah Perlakuan dengan program SPSS 24.

\begin{tabular}{|c|c|c|c|}
\hline $\mathbf{t}$ & Df & Sig (2-tailed) & Kesimpulan \\
\hline 1,667 & 46 & 0,102 & Tidak ada perbedaan \\
\hline
\end{tabular}

Berdasarkan tabel di atas dapat dilihat pada uji Independent Sample-T test yang telah dilakukan, nilai sig diperoleh 0,102. Nilai tersebut lebih dari 0,05 ( $s i g>0,05$ ) sehingga $H_{0}$ diterima, yang berarti tidak terdapat perbedaan kemampuan pemecahan masalah biologi siswa antara kelas yang menggunakan model kooperatif tipe TAI dengan kelas yang menggunakan model pembelajaran PBL.

Sebelum diberikan perlakuan dengan model pembelajaran kooperatif tipe Team Assisted Individualization dan model Problem Based Learning, hasil kemampuan pemecahan masalah biologi siswa MAN 1 kota Ternate kelas $\mathrm{X}$ sangat rendah. Rendahnya kemampuan pemecahan masalah biologis terlihat dari data pretest yang menunjukkan 48 siswa yang mengikuti tes awal, tidak seorangpun yang mencapai Kriteria Ketuntasan Minimum (KKM) yaitu 70.

Peningkatan kemampuan pemecahan masalah biologi siswa kelas $\mathrm{X}$ dalam penelitian ini dapat dilihat dari interpretasi $\mathrm{N}$-Gain. Interpretasi $\mathrm{N}$-Gain pada kelas eksprimen dengan menggunakan model kooperatif tipe Team Assisted Individualization dan pada kelas eksperimen dengan menggunakan model Problem Based Learning untuk kemampuan pemecahan masalah biologi siswa adalah sedang. Hal ini menunjukkan peningkatan kemampuan 
pemecahan masalah biologis siswa setelah diterapkannya model Team Assisted Individualization dan Problem Based Learning sedang.

Perbedaan peningkatan kemampuan pemecahan masalah biologis siswa setelah diterapkannya model kooperatif tipe Team assisted Individualization dan model Problem Based Learning dapat dilihat dengan membandingkan hasil kerja siswa pada kelas Team Assisted Individualization dengan kelas Problem Based Learning, dari hasil kerja siswa dapat disimpulkan bahwa tidak terdapat perbedaan peningkatan kemampuan pemecahan masalah biologis antara kelas yang diterapkan model pembelajaran kooperatif tipe Team assisted Individualization dengan kelas yang diterapkan model Problem Based Learning. Tidak ada peningkatan kemampuan pemecahan masalah biologis ini terlihat ketika hasil kerja siswa pada kelas Team Assisted Individualization sama dengan hasil kerja siswa di kelas PBL.

Selain dengan melihat hasil kerja siswa pada kelas Team Assisted Individualization dengan kelas Problem Based Learning, tidak terdapat perbedaan peningkatan kemampuan pemecahan masalah biologis juga terlihat pada hasil pengujian hipotesis dengan Independent Sample-T test dan N-Gain (g) pada kedua kelas eksperimen. Pada pengujian Independent Sample-T test diperoleh nilai sig (2-tailed) lebih besar dari $0,05(s i g>0,05)$ yang berarti tidak terdapat perbedaan peningkatan kemampuan pemecahan masalah biologis siswa antara kelas yang menggunakan model kooperatif tipe TAI dengan kelas yang menggunakan model PBL.

Pada pengujian dengan N-Gain (g) menunjukkan peningkatan kemampuan pemecahan masalah biologis siswa pada kelas Team Assisted Individualization sama dengan kelas Problem Based Learning. Selain itu, secara keseluruhan kedua kelas memiliki peningkatan kemampuan pemecahan masalah biologis yang sama yaitu sedang. Oleh karenanya, dapat disimpulkan tidak terdapat perbedaan peningkatan kemampuan pemecahan masalah biologis siswa antara kelas yang menggunakan model kooperatif tipe TAI dengan kelas yang menggunakan model PBL. Hal tersebut sama dengan apa yang dihipotesiskan bahwa tidak terdapat perbedaan peningkatan kemampuan pemecahan masalah biologis siswa antara kelas yang menggunakan model kooperatif tipe Team Assisted Individualization dengan kelas yang menggunakan model pembelajaran Problem Based Learning.

Berdasarkan karakteristik kedua pembelajaran tersebut merupakan suatu hal yang wajar jika tidak terdapat perbedaan hasil kemampuan pemecahan masalah matematis yang diperoleh siswa setelah mengikuti pembelajaran. Pada pembelajaran dengan model Problem Based Learning siswa dituntut untuk mengidentifikasi masalah yang diberikan, memilih strategi pemecahan masalah, menerapkan strategi untuk menyelesaikan berbagai masalah dalam matematika dan memeriksa kebenaran jawaban. Selain itu, pada pembelajaran dengan model Problem Based Learning mengawali kegiatan pembelajaran dengan mengorientasikan siswa kepada masalah konstektual. Kemudian memadukan investigasi mandiri maupun investigasi kelompok, mengklarifikasi istilah, mengorganisasikan belajar siswa, penyelidikan dan diskusi, melaporkan hasil diskusi, dan pemberian penilaian. Pada realisasi model PBL ini kedudukan guru sebagai fasilitator yang bertugas untuk mengawasi berjalannya diskusi dengan baik dan jika diperlukan guru sebagai fasilitator dapat memberikan petunjuk.

Prinsip utama model pembelajaran Problem Based Learning adalah penggunaan masalah nyata sebagai sarana bagi peserta 
Perbedaan Peningkatan Kemampuan Pemecahan Masalah Biologi Siswa dengan Menggunakan Model Kooperatif Team Assisted Individualization dan Problem Based Learning

didik untuk mengembangkan pengetahuan dan sekaligus mengembangkan kemampuan berfikir kritis dan kemampuan berfikir kritis dan kemampuan pemecahan masalah. Angkotasan N dan Suryanto mengatakan bahwa pada pembelajaran dengan model Problem Based Learning, siswa diperkenalkan dengan masalah autentik sehingga siswa dibantu untuk melakukan investigasi [3]. Proses investigasi yang melibatkan siswa secara langsung memungkinkan siswa untuk mengidentifikasikan masalah, memahami masalah dan menyelesaikannya sehingga pada akhirnya memperoleh pengetahuan baru.

Masalah yang diajukan dalam Problem Based Learning bersifat kompleks. Siswa bekerja dalam kelompok untuk mengidentifikasi apa yang mereka perlukan untuk menyelesaikan masalah, melibatkan siswa dalam kemandirian, menerapkan pengetahuan yang mereka miliki pada masalah dan merefleksi apa yang mereka pelajari.

\section{KESIMPULAN}

Berdasarkan hasil analisis data dan pembahasan sebelumnya, maka dapat diambil kesimpulan sebagai berikut.

1. Terdapat peningkatan kemampuan pemecahan masalah biologis siswa kelas X MAN 1 Kota Ternate tahun ajaran 2017/2018 setelah diterapkannya model pembelajaran kooperatif tipe Team Assisted Individualization.

2. Terdapat peningkatan kemampuan pemecahan masalah biologis siswa kelas X MAN 1 Kota Ternate tahun ajaran 2017/2018 setelah diterapkannya model pembelajaran Problem Based Learning .

3. Tidak terdapat perbedaan peningkatan kemampuan pemecahan masalah biologis siswa antara kelas yang menggunakan model pembelajaran cooperative tipe Team Assisted Individualizalion dengan kelas yang menggunakan model pembelajaran problem based learning

\section{DAFTAR PUSTAKA}

[1] M. Faturrahman. 2015. Model-Model Pembelajaran Inovatif. Yogyakarta: Ar-Ruzz Media,

[2] A. Kurniawan. 2013. "Penggunaan Model Pembelajaran Tipe Team Assisted Individualization (TAI) dalam Peningkatan Hasil Belajar Matematika Siswa Kelas V SDN Pagubungon Kulon 04 Tahun Ajaran 2012/2013," Universitas Sebelas Maret. Unpublished

[4] Angkotasan. 2013. "Model PBL dan Cooperative Learning Tipe TAI Ditinjau dari Aspek Kemampuan Berpikir Reflektif dan Pemecahan Masalah Matematis". Jurnal Pendidikan Matematika. Vol 8(1)

[3] Arilda, Et.al. 2018 "Pebedaan Hasil Belajar IPA Biologi Menggunakan Model Pembelajaran Kooperatif Tipe Team Assisted Individualization dengan Tipe Mind Mapping pada Siswa Kelas VII SMP Negeri 19 Mataram," J. Pijar MIPA, vol. 13(2): 98

[4] Nuryanto. et Al. 2015. "Penerapan Model Pembelajaran Problem Based Learning (Pbl) dilengkapi Macromedia Flash untuk Meningkatkan Kemampuan Berpikir Kritis Dan Prestasi Belajar Siswa Pada Materi Pokok Termokimia Kelas XI Siswa SMA Negeri 2 Karanganyar Tahun Pelajaran 2014/2015," J. Pendidik. Kim., vol. 4, no. 4, pp. 87-94.

[5] Suyadi, Strategi Pembelajaran Pendidikan Karakter. Bandung: PT Remaja Rosdakarya, 2013. 
[6] R. I. Arends, Classroom Instruction and Management. New York: Mc Graw Hill Companies., 1997.

[7] J. Dewey, Democracy and Education. Chicago: Schuster, 1997.

[8] M. F. B. Paloloang. 2014. "Penerapan Model Problem Based Learning (PBL) untuk Meningkatkan Hasil Belajar Siswa pada Materi Panjang Garis Singgung Persekutuan Dua Lingkaran di Kelas VIII SMP Negeri 19 Palu," J. Elektron. Pendidik. Mat. Tadulako, Vol. 2(1): 67-77.

[9] Stephen B.Klein, LearningPrincipples and Applications. New York: Mc Graw-Hill, Inc., 1996.

[10] R. . Arends, Exploring Teaching: An Introduction to Education. New York: Mc Graw-Hill Companies., 2001.

[11] Wina Sanjaya, Strategi Pembelajaran Berorientasi Standar Proses Pendidikan. Jakarta: Kencana Prenda Media, 2006.

[12] Sugiyono. 2006. Metode Penelitian Kuantitatif Kualitatif dan R\&D. Bandung: Alfabeta. 